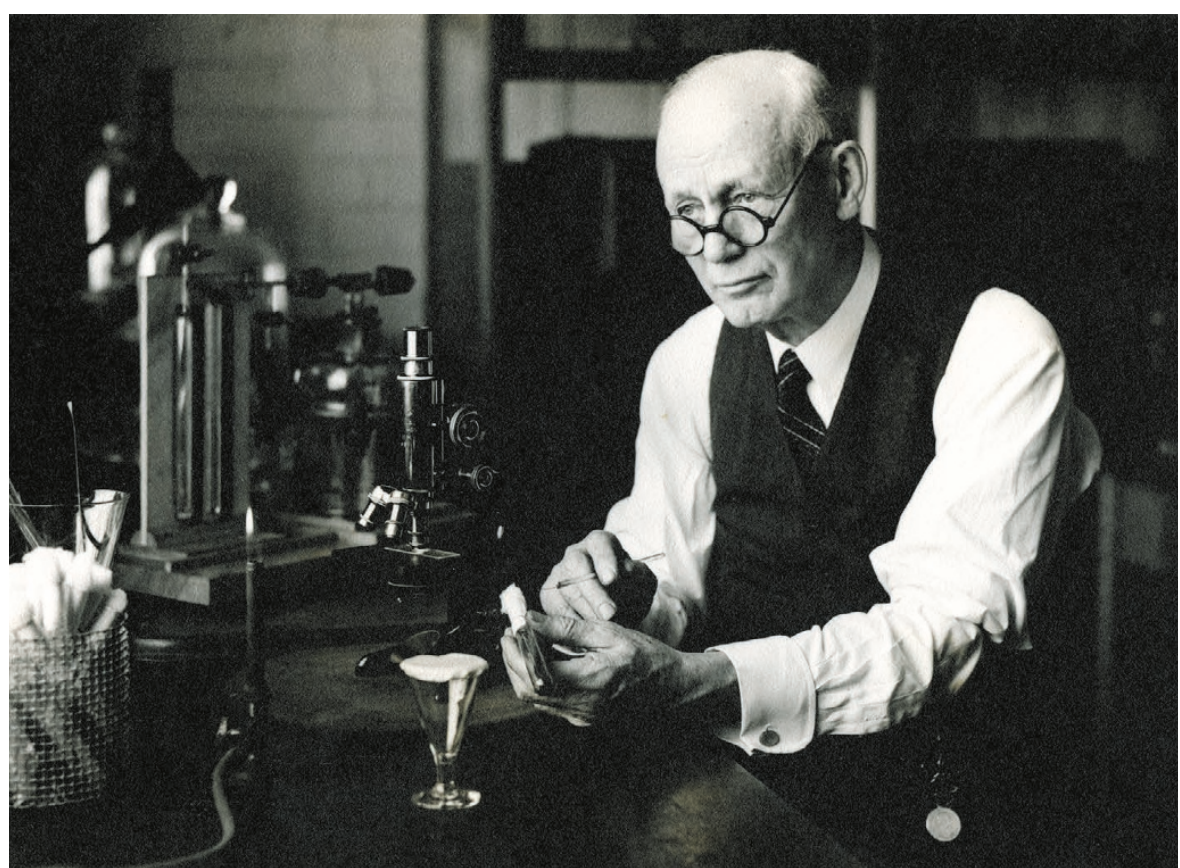

Frederick Novy, pictured in 1938, championed the early study of microorganisms.

MEDICAL RESEARCH

\title{
Pitching the big tent of modern microbiology
}

\section{Andrew Jermy explores the work of a bacteriologist who championed basic research and reproducibility.}

$\mathrm{T}$ he 'hero narrative' of science that honours stars such as Isaac Newton and Marie Curie often obscures the multitudes who lay the foundations - that centuries-old chain of curious minds. In this biography, physician and historian Powel Kazanjian pulls one from that multitude into the light: microbiology pioneer Frederick Novy.

Kazanjian's detailed and authoritative account reveals how Novy (1864-1957) did fundamental work that shaped the field's development, and introduced basic research into medical training. Novy grew up in Chicago, Illinois. Like many of his US contemporaries in the transitional, industrializing latter half of the nineteenth century, he explored science in school. As a youth, he conducted chemical reactions under the back steps of his home, with inevitably explosive results, and saved US\$60 from a job in the Chicago Public Library to buy a microscope and investigate life invisible to the naked eye.

At the University of Michigan in Ann Arbor, he trained as a chemist before moving to medical school, but never practised as a physician, instead taking up a post under
Frederick

Novy and the

Development of

Bacteriology in

Medicine

POWEL H. KAZANJIAN

Rutgers University

Press: 2017.

\section{of bacteriology and germ theory.}

Back in Ann Arbor, Vaughan and Novy established the Michigan Hygienic Laboratory, the first US public-health laboratory to be associated with a university. This academic affiliation went hand in hand with a different approach. As well as providing services for public health, the lab's goal was to do original bacteriology research. Novy designed and built instruments that helped to establish that respiration is a basic metabolic activity in unicellular organisms, including the bacterium that causes TB, Mycobacterium tuberculosis. His tools enabled the culture and study of numerous new groups, including anaerobic bacteria, the double-membraned spirochaetes and parasitic trypanosomes. Novy also recognized that bacteriological methods could be used to investigate other microorganisms: protozoa and viruses. Arguing for a more inclusive definition of 'bacteriology', he became an early champion of the big tent that is modern microbiology. The lab brought basic research and experimentation into the US medical curriculum, and Novy sought to inoculate medical students with a spirit of scepticism, to encourage them to question their professors and to instil "the power to think and do".

Although the 150 years since Novy's birth have seen astonishing advances in technological capability - for visualizing microbes and for understanding the mechanisms by which they interact with the environment - it is remarkable how familiar much of his world is. In Novy's time, most microbiological research was translational, looking at which microbes caused disease and how they could be stopped, but he fought for fundamental research. That tension reverberates still. During a suspected outbreak of bubonic plague in San Francisco, California, in 1901, officials concerned about commercial interests initially rejected evidence from Novy, who had been brought in as an independent specialist. There are echoes of similar conflicts today, when evidence-based health recommendations, for instance on vaccination, are ignored.

Testimonials from Novy's students describe him as draconian about reproducibility, railing against those who rushed to publish or cut short bibliographies to limit printing costs or through neglect of the literature. Many PhD students and postdocs will commiserate with one pupil, Paul de Kruif, who noted that Novy would "rip my scientific reports to bits! In his precise, minute handwriting, he wrote 'bosh' and 'twaddle' and 'rot' on the margin. He growled that every one of my conclusions was unjustified, exaggerated, untenable." De Kruif went on to collaborate with author Sinclair Lewis on the 1925 novel Arrowsmith, which won a Pulitzer prize (that Lewis declined); a central character, the truth-seeking scientist Max Gottlieb, is based partly on Novy.

One wonders what Novy might have scribbled in the margins of Kazanjian's biography. The era and subject are fascinating, and Novy's part in the development of microbiology and medical education is important. But there is little sense of story in the narrative: it's not so much a page-turner as a dry historical record. In part, this may be a reflection of Novy's unshowy dedication, and the nature of science. What remains in the record is the research, and much less the researcher. Perhaps this is the final lesson to take from this tale: that to learn from our scientific past, we need to consider humanizing the way in which research is recorded and communicated, to tell the real story behind the work.

Andrew Jermy is chief editor of Nature Microbiology.

e-mail:a.jermy@nature.com 